\title{
APPLICATION OF ICT AS A TOOL IN REVITALIZING THE NIGERIAN EDUCATIONAL SYSTEM
}

\author{
EUGENIA NGOZI AMAKA, THERESA OTIJI, JANE IYAWA
}

\begin{abstract}
:
It is very appalling that Nigerian educational system has not deeply embraced the implementation of Information and Communications Technology (ICT) in educational system. ICT is a global link to all facets of life and educational system in Nigeria is left out in this new technological development. ICT which include radio, television, computer, internet among others have been praised as potentially powerful enabling tools for educational change and reform, but the Nigerian educational system has failed to create such enabling environment that will enhance effective implementation of ICT in educational system. There are lots of uncertainties that impede the effective implementation of ICT in Nigerian educational system, these factors include incompetency of the teachers, inadequate facilities, lack of refresher training courses given to teachers, insecurity challenges, and poor teaching methodology. Having seen the afore mentioned problems in Nigerian educational system, this research tends to address these problems by implementing the application of ICT in revitalizing the Nigerian educational system. This could be achieved by introducing ICT in the school system as well as given adequate supervision on the implementation to ensure a huge success. The research was guided by two research questions and a structured questionnaire to elicit information from the respondents. The research has proved that conducting refresher training for teachers, provision of adequate laboratory facilities, provision of conducive enabling environment, effective and cognitive teaching strategies and methods should be adopted to arose the learners interest and enhance the performances of the students. The researcher recommended that there should be a thorough supervision from the educational board to ensure adequate implementation of ICT in Nigerian educational system.
\end{abstract}

\section{Keywords:}

Criminalities, Digital, ICT, Kidnapping, Malfunctioning

JEL Classification: A31

\section{Authors:}

EUGENIA NGOZI AMAKA, Enugu State College of Education (Technical), Enugu, Nigeria, Email: ngoziamaka6011p@yahoo.com THERESA OTIJI, Enugu State College of Education (Technical), Enugu, Nigeria, Email: chinemeotigi@yahoo.com JANE IYAWA, FEDERAL COLLEGE OF EDUCATION (TECHNICAL), ASABA, DELTA STATE, Nigeria, Email: iyawaben@hotmail.com

\section{Citation:}

EUGENIA NGOZI AMAKA, THERESA OTIJI, JANE IYAWA (2020). Application of ICT as a Tool in 
Revitalizing the Nigerian Educational System. International Journal of Teaching and Education, Vol. VIII(1), pp. 1-10., 10.20472/TE.2020.8.1.001 


\section{INTRODUCTION}

Education no matter the angle the educators are coming from, is all about gaining positive knowledge and being able to face the educational challenges in the future. The educational objectives in its existence especially in this $21^{\text {st }}$ century cannot be fully achieved without having a conducive atmospheric condition for learning activities, total embracement of the technological tools in the educational system, adequate facilities, competent personnel for proper implementation of the educational curriculum, among others.

It is very alarming that education in Nigeria in this $21^{\text {st }}$ century is being confronted with a very serious educational menace due to insecurity challenges, non-compliance of ICT as a technological tool in the educational system, inadequate facilities, lack of regular power supply, and lack of government support to aid the educational difficulties in the country.

These, however, have made the attainment of the educational goal in Nigeria especially in the Northern part of Nigeria to be unachievable. Also, it has absolutely affected the mind-set of the youths, which then put them in a very high rate of committing all sorts of crimes such as kidnapping, robbery attack, rapping among others. There is need for emergency call on individuals, organisations, educationalists, stakeholders and government representatives in Nigeria to come together and embrace the western education through the total adoption of Information and Communications Technologies (ICTs) to support, enhance and optimise the fastest delivery of teaching and learning methods.

This, if well implemented could tackle the aforementioned problem of the educational system in Nigeria and make the objectives of the educational system to be realistic. Thus, the attainment of educational tree in Nigeria should be a focus of every citizen of the country to impart positively and change the mind-set of the youths for tomorrow. The educational tree in Nigeria goes thus: 


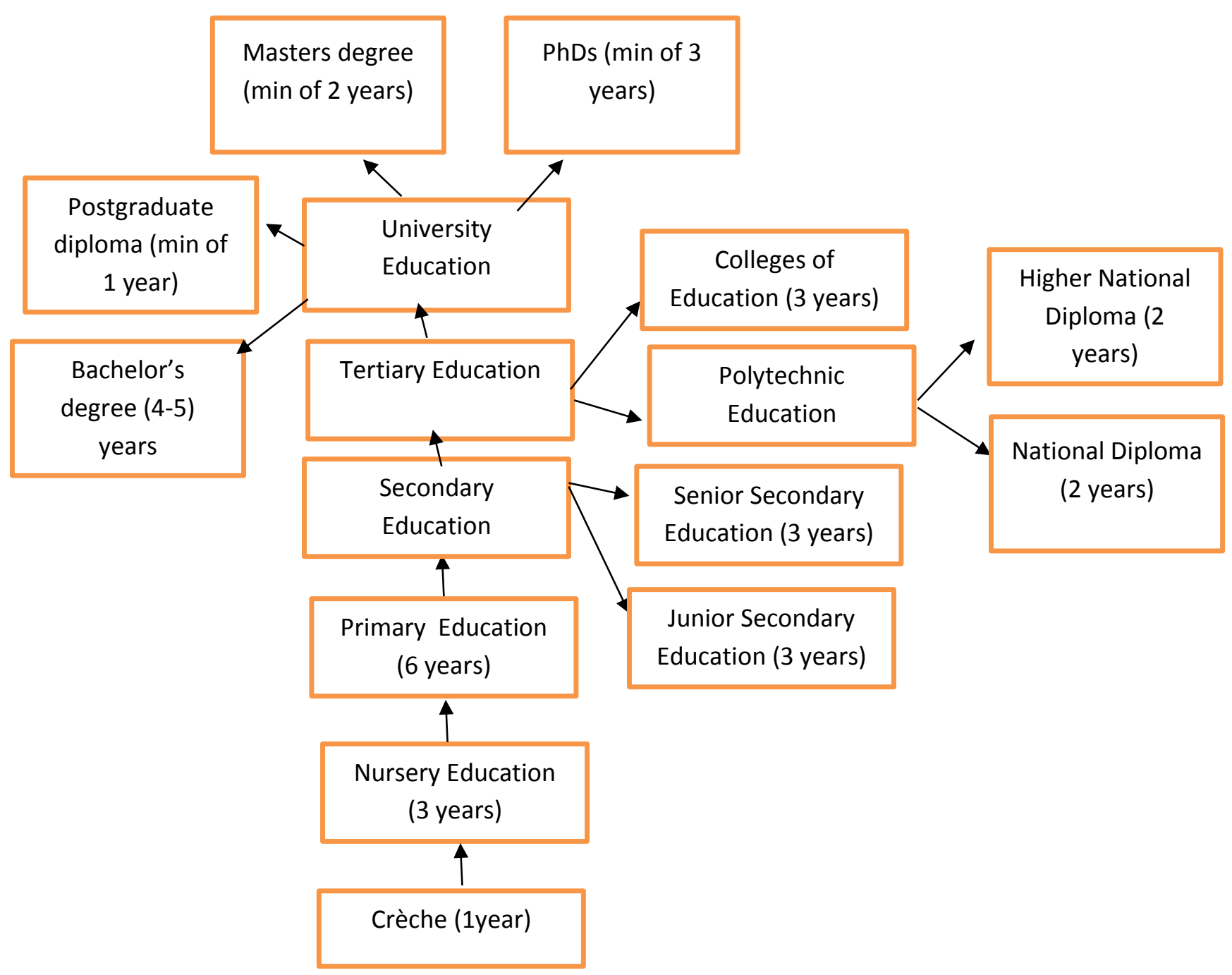

Figure1: Nigerian education tree

Source: Federal Ministry of Education.

\section{OBJECTIVE OF THE STUDY}

i. $\quad$ To introduce ICT as a digital tool in educational system in Nigeria.

ii. To tackle security challenges that hinder a smooth functional of educational system in Nigeria via the use of gadgets.

iii. To re-introduce orientation system on the need to have western education in this $21^{\text {st }}$ century to all Nigerians. 


\section{RESEARCH QUESTIONS}

i. What are the causes of malfunctioning of educational system in Nigeria?

ii. How could the application of ICT minimise the educational challenges in Nigeria?

\section{SIGNIFICANCE OF THE STUDY}

Generally, the importance of education to individuals, growth and development of the nation cannot be over emphasized, especially if its relevance is extended to the Northern part of Nigeria. The total embracement of ICT in educational system in the northern part of Nigeria can positively impact on the youths of the Northerners and Nigeria as a country. This will curb the educational menace in the society. Also, the study would be of immense benefit to the various stakeholders, in both security matters and curriculum planners in the country on how to move the country forward.

\section{REVIEW OF RELATED LITERATURE}

Information and communication technology (ICT) which include computers, internet and other digital delivery service systems such as projectors, radios, and televisions broaden a wide access to education and Nigeria cannot be an exception to this platform of learning innovation. Its benefits especially on education cannot be over emphasized and there is need to channel the educational services in Nigeria to ICT implementation since insecurity in the country has persisted.

Fisseha, (2011) states that the introduction and integration of ICT at different levels and various types of education is the most challenging undertaking. Failure to meet the challenges would mean a further widening of the knowledge gap and deepening of existing economic and social inequalities among developed and developing countries. Also, the use of ICTs in education shifts the learning approaches, as put by (Bransford, Brown and Cooking,1999) cited in Fisseha 2011; teachers' reluctance to adopt innovations need to be seen in the context of existing technology and commitment; Fllen (1989) cited in Fisseha (2011).

Watson (2001) cited in Fisseha (2011) states that changes or improvement can happen at schools if teachers understand themselves and understood by others. It is glaring that most teachers, especially in the northern part of Nigeria are not competent enough to transform the traditional method of teaching to digital approach, in such a situation, it is still problematic to make a positive change in education. Voogt (2003) cited in Fisseha (2011) described ICT as a medium of instruction.

Crawfurd (2015) believed that education is a vital instrument to be used in achieving growth and national development of a country. Today the educational system in Nigeria is beyond doubt in alarming state of condition. It is obvious that many schools in Nigeria especially in the Northern part of Nigeria have been shut down due to insecurity challenges in that country. Also, Iyabo, (2018) said that many children cannot attend school because of the fear of Boko Haram in that geo-graphical region and increasing kidnapping rate 
across the country can be viewed as a law enforcement failure as security operatives have failed to send out a forceful message on the repercussion of such crimes.

According to the Nigerian Education Data Survey (NEDS,2010) as cited in Salah (2011), constant attack makes it even harder for teachers and stakeholders to persuade parents or guardians to allow their children stay on at school. The issue of insecurity in Nigeria has compelled school children to drop out of the school. Drop out students are liable to all sorts of criminalities in the society. Criminal activities perpetuated in the Nigeria are traced to those who dropped out of school.

\section{THE ANALYSIS OF EDUCATIONAL CHALLENGES IN NIGERIA ESPECIALLY IN THE NORTHERN PART OF NIGERIA}

\section{i. RESEARCH QUESTION 1:}

What are the causes of malfunctioning of educational system in Nigeria?

TABLE 1:

\begin{tabular}{|l|l|l|l|l|l|l|l|}
\hline S/N & Items & SA & A & D & SD & X- & Decision \\
\hline 1 & $\begin{array}{l}\text { Lack of trained ICT } \\
\text { personnel }\end{array}$ & 95 & 5 & - & - & 3.42 & Agreed \\
\hline 2 & Lack of security control & 100 & - & - & - & 3.50 & Agreed \\
\hline 3 & $\begin{array}{l}\text { Non-adoption of ICT in } \\
\text { educational system }\end{array}$ & 95 & 3 & 2 & - & 3.42 & Agreed \\
\hline 4 & $\begin{array}{l}\text { Non-compliance of } \\
\text { parents to send their } \\
\text { children to school }\end{array}$ & 92 & 5 & 3 & - & 3.25 & Agreed \\
\hline 5 & $\begin{array}{l}\text { Non availability of the } \\
\text { ICT tools as instructional } \\
\text { materials }\end{array}$ & 100 & - & - & - & 3.31 & Agreed \\
\hline 6 & $\begin{array}{l}\text { Lack of competency } \\
\text { displayed from available } \\
\text { teachers }\end{array}$ & 94 & 3 & 3 & - & 3.42 & Agreed \\
\hline 7 & Lack of infrastructure & 100 & - & - & - & 3.50 & Agreed \\
\hline 8 & $\begin{array}{l}\text { Lack of regular power } \\
\text { supply }\end{array}$ & 100 & - & - & - & 3.50 & Agreed \\
\hline
\end{tabular}

The analysis of the above table has shown that the educational system in Nigeria especially in the Northern part of Nigeria is deeply menaced.

\section{RESEARCH QUESTION 2:}

How could the application of ICT minimise the educational challenges in Nigeria?

TABLE 2:

\begin{tabular}{|l|l|l|l|l|l|l|l|}
\hline S/N & Items & SA & A & D & SD & X- & Decision \\
\hline 1 & Adequate security measures to be taken & 100 & - & - & - & 3.50 & Agreed \\
\hline
\end{tabular}




\begin{tabular}{|l|l|l|l|l|l|l|l|}
\hline 2 & $\begin{array}{l}\text { Re-orientation of individuals, parents, } \\
\text { guardians, groups etc on the importance } \\
\text { of ICT in educational system }\end{array}$ & 92 & 8 & - & - & 3.28 & Agreed \\
\hline 3 & $\begin{array}{l}\text { Constant re-training of teachers to } \\
\text { upgrade their knowledge to ICT based. }\end{array}$ & 96 & 4 & - & - & 3.38 & Agreed \\
\hline 4 & ICT adoption in educational system & 97 & 3 & - & - & 3.42 & Agreed \\
\hline 5 & Provision of steady power supply & 98 & 2 & - & - & 3.43 & Agreed \\
\hline 6 & $\begin{array}{l}\text { Adequate supervision of teachers to } \\
\text { ensure proper implementation of ICT in } \\
\text { educational system }\end{array}$ & 94 & 3 & 3 & - & 3.26 & Agreed \\
\hline 7 & $\begin{array}{l}\text { Government's intervention to aid the } \\
\text { difficulties of actualizing the } \\
\text { educational objectives in Nigeria. }\end{array}$ & 100 & - & - & - & 3.50 & Agreed \\
\hline 8 & Provision of jobs on graduation & 100 & - & - & - & 3.50 & Agreed \\
\hline
\end{tabular}

The above table depicts the possible ways to curb the problems of educational system in Nigeria.

\section{STATE OF EDUCATION IN NIGERIA ESPECIALLY IN THE NORTHERN PART OF NIGERIA}

1. The photography below depicts the poor learning condition in the Northern part of Nigeria. In this $21^{\text {st }}$ century, wall is used in teaching pupils while these children are regarded as the future leaders of tomorrow without proper attention given to them. A child found in this environment has no doubt feel inferior before his or her mates in a better environment. Also, an instructor guiding these children in this condition has little to offer them. This shows that educational approach in deeply lacking in the Northern part of Nigeria.

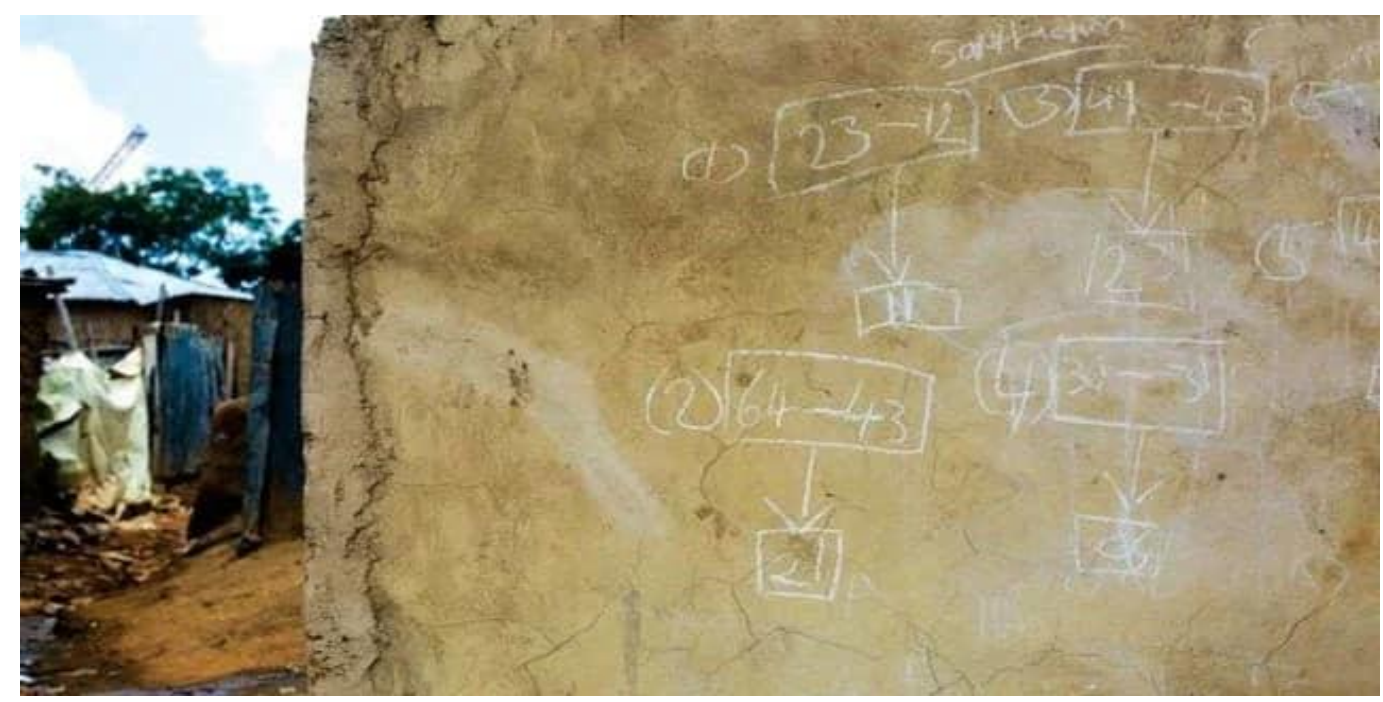

Figure 2: A wall converted for learning process. 
2. The photography of dilapidated building behind the instructor below was supposed to be a classroom. No student or instructor will be comfortable to stay in such building for learning. Learning is all about having a good comfort and as well as being happy. Sequeira (2012) states that you cannot motivate others if you are not self-motivated; and learning is both motives (motives are not seen) and behaviour but only behaviour is seen, learning is internal, performance is external.

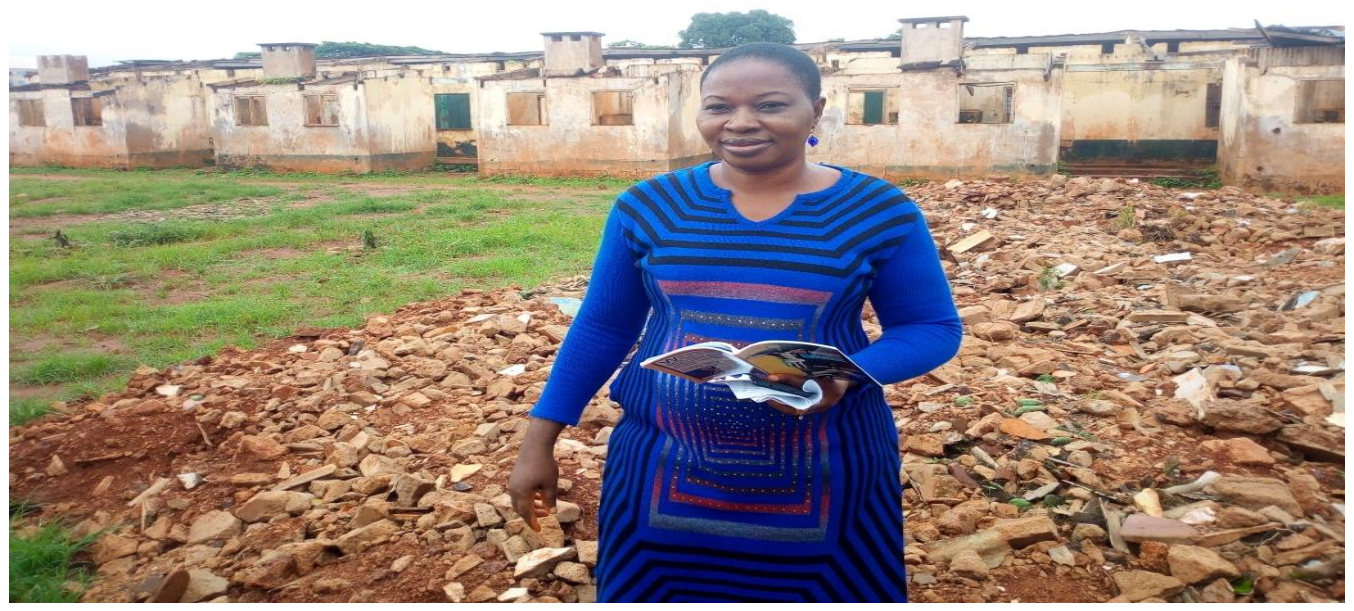

Figure 3: A photography of a dilapidated classroom.

3. It is shocking that both the learners and instructors are subjected to unbearable condition for learning processes due to unavailable classrooms. The photography below depicts where both the learners and the instructor are standing outside the classroom environment for learning processes. Most of the classrooms in the northern part of Nigeria have been destroyed by insurgents and this has made learning to be very appalling.

\begin{tabular}{|l|}
\hline Figure 4: \\
A \\
photogra \\
phy of \\
both the \\
learners \\
and \\
instructor \\
during \\
learning \\
process. \\
\hline
\end{tabular}

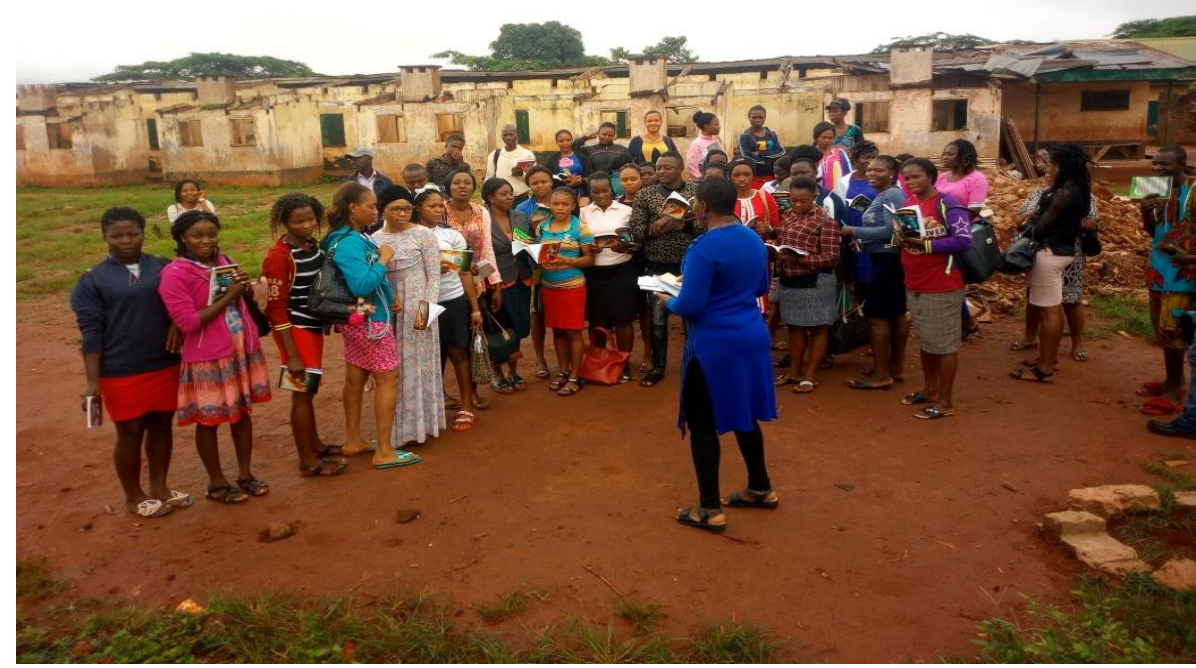




\section{POSSIBLE WAYS TO ADDRESS THE AFOREMENTIONED PROBLEMS OF EDUCATIONAL SYSTEM IN NIGERIA.}

The problems of educational system in Nigeria are man-made and should be addressed properly to curb its effect in the society. The following are the possible ways to tackle such problems;

i. The government should employ adequate security measures to avert further destruction of classrooms and talents of further leaders in the country. Also, they should try to put in place all the dilapidated structures for easy learning Process.

ii. There is need to adopt the application of ICT as a digital tool to enhance the teaching and learning processes in the country.

iii. The government should endeavour to maintain a steady power supply to ensure adequate utilization of ICT in the educational sector in Nigeria.

iv. The government or those concerned should provide financial assistance to aid the difficulties of educational sector in Nigeria.

\section{DISCUSSION OF THE FINDINGS}

The analysis of table 1 above shows that educational system in Nigeria is deeply alarming. The bad state of condition in Nigeria has absolutely affected the growth and development of the country. Many of their youths are out of school and their mind-sets have been corrupted negatively, that worst things are happening regularly, which persistently incites crisis in the country. Though, this paper suggested various ways in which the problems of educational system in Nigeria could be tackled, which include employing adequate security measures, adoption of ICT application in educational sector among others.

\section{CONCLUSION}

It is glaring that western education is a key instrument to growth and development of any nation. Therefore, adequate attention should be given to the educational system in Nigeria especially in the northern part of Nigeria, in order to avert any form of educational malfunctioning.

\section{RECOMMENDATION}

The study recommends that adequate measures should be taken to ensure that:

i. Security measures should be fully provided to protect lives and properties to the citizens of Nigerians

ii. Regular orientation on the importance of western education should be provided to individuals, parents, guardians, or groups

iii. Government should ensure adequate adoption of ICT application in educational sector in the northern part of Nigeria, re-training of teachers to upgrade their knowledge to ICT based, provision of jobs on graduation and giving financial 
assistance to aid the difficulties of actualizing the educational objectives in the northern part of Nigeria.

\section{REFERENCES}

1. Fisseha Mikre (2011); The Role of ICT in Education:

Review article with emphasis to the computer and internet.

2. Garba Mohammad (2015); Northern Nigeria lagging behind in Education. Premium times Nigeria.https://premiumtimesng.com.

3. Iyabo Lawel (2018); How insecurity is running education in Nigeria. Guardian Nigeria https://guardian.ng.

4. Kiew-Heong Yap, Zakiah Saleh and Masourd Abessi (2011). Internet Financial Reporting and Corporate Governance in Malayasia., Australia journal of basic and applied sciences Vol.5, No. 10. Pp 1273-1289.

5. Sara Humphery \& Lee Grawfurd (2015); Review of the literature on Basic Education in Nigeria. Issues of access, quality, equity and impact.

6. Sequeira A.H. (2012); Introduction to concept of Teaching and Learning. https://doi.org/10.2139/ssrn.2150166 